Arq. Bras. Med. Vet. Zootec., v.66, n.2, p.471-480, 2014

\title{
Assessment of heavy metal residues in Brazilian poultry and swine tissue
}

\author{
[Avaliação de resíduos de metais pesados em tecidos de aves e suínos] \\ J. F. Alkmim Filho ${ }^{1}$, A. Germano ${ }^{1}$, W.L.S. Dibai ${ }^{1}$, E.A. Vargas $^{1}$, M.M. Melo ${ }^{2 *}$ \\ ${ }^{1}$ Laboratório Nacional Agropecuário (Lanagro) - Pedro Leopoldo, MG \\ ${ }^{2}$ Escola de Veterinária - Universidade Federal de Minas Gerais - Belo Horizonte, MG
}

\begin{abstract}
The aim of this study was to investigate the presence of arsenic, lead and cadmium residues in samples of liver, kidney and muscle of poultry and swine during the years from 2002 to 2008 . A total of 1978 samples were analyzed: 1031 of poultry and 947 of swine from Brazilian slaughterhouses. The samples were analyzed at the National Agricultural Laboratory using the atomic absorption spectrometry technique. In poultry, the arsenic residues were detected in $53.6 \%$ of liver samples, although no results have exceeded the MRL. In kidneys, $39.7 \%$ of the samples showed measurable residues and there was no violation of the limits. Regarding lead, there were 5 contaminated liver samples and 24 contaminated kidney samples ( 1.5 and 3.6\% respectively). In muscle tissue there was only one sample with residues. For cadmium, 3.8\% of the samples were found below MRL. Cadmium residues were found in 110 kidney samples (16.3\% of tested), but only one exceeded the legislation limits. In swine, arsenic residues were detected in $15.3 \%$ of liver samples, although no results exceeded the MRL. In kidneys, $14.2 \%$ of samples showed measurable residues. However, there was no violation of limits. Regarding lead levels, 7 liver samples and 18 kidney samples were contaminated (2.6 and 2.7\% respectively). Cadmium was found below MRL in $14.9 \%$ of the analyzed samples. In kidneys, 448 samples (67.8\% of the total tested) had cadmium residues and 4 samples exceeded the legislation limits. During the seven years of study (20022008), only $5(0.25 \%)$ out of 1978 tested samples violated the Brazilian law. However, even with low levels of violation, monitoring is essential, since the number of samples with residues was often greater than the number of violations, and in some cases, such as cadmium in the kidneys, the majority of samples contained quantifiable residues and with levels often near the limits.
\end{abstract}

Keywords: trace elements, arsenic, cadmium, lead

\section{RESUMO}

Objetivou-se investigar a presença de resíduos de arsênico, chumbo e cádmio em amostras de fígado, rins e músculo de aves e suínos, durante os anos de 2002 a 2008. Um total de 1.978 amostras foi analisado: 1031 de aves e 947 de suínos provenientes de matadouros brasileiros. As amostras foram analisadas no Laboratório Nacional Agropecuário (Lanagro), sendo utilizada a técnica de espectrometria de absorção atômica. Em aves, os resíduos de arsênico foram detectados em 53,6\% das amostras de figado, embora sem exceder o LMR. Nos rins, 39,7\% das amostras mostraram resíduos mensuráveis e não houve violação dos limites. Em relação ao chumbo, cinco amostras de fígado e 24 de amostras de rins estavam contaminadas (1,5 e 3,6\%, respectivamente). No tecido muscular, houve apenas uma amostra com resíduos. Para o cádmio, 3,8\% das amostras apresentavam valores abaixo do LMR. Resíduos de cádmio foram encontrados em 110 amostras de rins (16,3\% testados), mas apenas uma ultrapassou o limite máximo permitido pela legislação nacional. Em suínos, resíduos de arsênico foram detectados em 15,3\% das amostras de fígado, sem exceder o LMR. Nos rins, 14,2\% das amostras apresentaram resíduos mensuráveis, sem, no entanto, haver violação dos limites. No que diz respeito aos niveis de chumbo, sete amostras de figado e 18 amostras de rins estavam contaminadas (2,6 e 2,7\%, respectivamente). $O$ cádmio foi encontrado abaixo do LMR em 14,9\% das amostras analisadas. Nos rins,

Recebido em 27 de junho de 2013

Aceito em 16 de dezembro de 2013

E-mail: mariliamm@ufmg.br 
448 amostras $(67,8 \%$ do total analisado) tinham resíduos de cádmio e quatro amostras excederam o LMR. Durante os sete anos de estudo (2002-2008), apenas cinco (0,25\%) das 1.978 amostras analisadas (de aves e suínos) violaram a lei brasileira. Entretanto, mesmo com baixos níveis de violação, o controle é essencial, uma vez que o número de amostras com resíduos foi muitas vezes maior do que o número de violações e, em alguns casos, como o cádmio nos rins, a maioria das amostras continha resíduos quantificáveis e com níveis, muitas vezes, perto do LMR.

Palavras-chave: elementos traço, arsênico, cádmio, chumbo

\section{INTRODUCTION}

Among the obstacles currently faced by the Brazilian meat industry, one of the most concerning problems is, undoubtedly, the potential presence of residues in animal tissues, giving emphasis to toxic metals. Moreover, cadmium, arsenic and lead stand out as the main inorganic pollutants present in products of animal origin.

The presence of heavy metals in tissues and products of animal origin might be a result of a natural occurrence of those elements in the soil, as well as harmful industrial activity, which causes environmental contamination. These substances have a diverse toxicity degree. Hence, the analysis of these residues is of vital importance, aiming to obtain information on the regional levels. Eventually, such data will allow the identification of areas of environmental pollution (WHO, 2007).

Heavy metals constitute the greatest source of inorganic pollutant that affects soil and water, being introduced into the atmosphere mainly through fertilizers, pesticides, combustion of coal and oil, vehicular emissions, mining, foundry, refinement and incineration of urban residues (Pulles et al., 2012; Gunawardena et al., 2013).

Arsenic is a metalloid that occurs in inorganic and organic forms and is found in the environment, both naturally occurring and as a result of human activity. The inorganic forms of arsenic are more toxic than organic ones. However, so far, most of the data regarding arsenic occurrence in food, gathered under the official control of foodstuff, is still reported as total arsenic, without differentiating the various types of arsenic in the diet (EFSA, 2009a, Carey et al., 2010). Human activities, such as the burning of fossil fuels, metal smelting and the production of semiconductors and glasses, have stimulated the accumulation of arsenic in the environment. Arsenic is also a component of many commonly used materials, including wood, pigments, insecticides, herbicides, rodenticides and fungicides (Smedley and Kinniburgh, 2002).

Lead occurs as an environmental contaminant due to its wide industrial usage in the mining industry, petroleum, accumulators of paints and dyes, ceramics, printing and in military weapon industry (Tajkarimi et al., 2008). In recent years there has been a change in the use of lead. For example, in the production of metallic paints, for instance, it has been declining, whereas the demand for lead by battery industries has only increased (Pappas et al., 2007). The main sources of lead contamination are mining activities and the application of sewage sludge on agricultural soil. Concentrations above $600 \mu \mathrm{g} / \mathrm{kg}$ dry weight were reported in forages grown on soil subject to mining activities or in locations where sewage sludge was added. Furthermore, the processes of harvesting forage for conservation as silage or hay often result in the aggregation of soil collected along with the cultures. Therefore, high levels of lead may reflect contamination of soil with waste material (EFSA, 2004).

Cadmium is one of the five most toxic metals found in nature and it is not essential to human beings and domestic animals. It is found in biological tissues due to an exposure to contaminated food or environment, being also related to work activity. Its numerous industrial applications and its ability to mix with other metallic elements (mainly copper and zinc) favor the occurrence of environmental contamination (Reeves and Chaney, 2008). The International Agency of Cancer Research classified cadmium as a human carcinogen (Group 1) based on occupational studies. Data on human exposure to cadmium in the general population were statistically associated with increased risk of cancer in lungs, endometrial tissue, bladder and breast (EFSA, 2009b). 
Thereby, the aim of this study was to survey the presence of heavy metals residue in the liver, kidneys and muscle of poultry and swine species in Brazil.

\section{MATERIALS AND METHODS}

A total of 1978 samples was analyzed: 1031 of poultry and 947 of swine from Brazilian slaughterhouses, previously selected between the years 2002 and 2008. The drawing of the slaughterhouses was done in random order as determined by the National Programme for Control of Residues and Contaminants (PNCRC), and the sampling was conducted by federal agriculture fiscals who work in the drawn slaughterhouses (Brazil, 1999). All samples were identified with the origin of the slaughtered animals (state and municipality). The metals chosen in this study were cadmium, arsenic and lead. All tests were performed at the National Laboratory of Agriculture (LANAGRO -MG) during the years 2002, 2003, 2004, 2005, 2006, 2007 and 2008; having analyzed samples from 20 Brazilian states plus the Federal District.

The swine samples consisted of one or more tissues $(500 \mathrm{~g})$ selected from a single apparently healthy animal. These samples were collected from randomly selected animals immediately after stunning. Each poultry sample was obtained from animals of the same batch, until achieving the minimum quantity of $500 \mathrm{~g}$ of visceral tissue and muscle, separately. All samples were collected from liver, kidney and skeletal muscle, of which the latest was only analyzed when samples of liver and/or kidneys showed results above the maximum residue limit (MRL).

The atomic absorption spectrometer was PerkinElmer Analyst 100 (Norwalk, USA) equipped with a Perkin-Elmer model FIAS 400 flow injection system and Perkin-Elmer AS 90 autosampler. Silicone pump tubes (NaBH4:1.14 $\mathrm{mm}$ i.d., $\mathrm{HCl} 10 \%$ : $1.52 \mathrm{~mm}$, sample loading and waste: $3.17 \mathrm{~mm}$ ) were used throughout this study. All other tubing was made of polytetrafluoroethylene. Argon and acetylene were used as the transport gas. An electrically heated quartz tube was used as an atomizer.
The methods used in this study were the same used by the Ministry of Agriculture in Brazil (MAPA) in the analysis of inorganic contaminants; and they were based on the USDA (2001). The tests were previously validated using as reference standards from the 657/2002 decision by the European Community. This study used two testing methods, one for the determination of cadmium and lead and the other for the determination of arsenic, both by atomic absorption spectrophotometry.

The limits of detection and quantification defined in the validation procedures for cadmium were $90 \mu \mathrm{g} / \mathrm{kg}$ or $\mathrm{CC} \alpha$ and $100 \mu \mathrm{g} / \mathrm{kg}$ or $\mathrm{CC} \beta$, respectively. The limits of detection and quantification defined in the validation procedures for lead were $100 \mu \mathrm{g} / \mathrm{kg}$ or $\mathrm{CC} \alpha$ and $150 \mu \mathrm{g} / \mathrm{kg}$ or $\mathrm{CC} \beta$, respectively.

For arsenic determination the atomic absorption spectrophotometry (AAS) with hydride generation (HG-AAS) and automatic injection into the flow was used. The limits of detection and quantification were $15 \mu \mathrm{g} / \mathrm{kg}$ or $\mathrm{CC} \alpha$ and $30 \mu \mathrm{g} / \mathrm{kg}$ or $\mathrm{CC} \beta$, respectively.

Descriptive statistics were used to create charts and tables. Mean values, variances, standard deviations, and the coefficient of variation were determined. The 10, 50 and 90 percentiles and frequency distributions were also calculated.

\section{RESULTS AND DISCUSSION}

In the years of 2002 to 2008, 1031 poultry samples were analyzed (Table 1).

During the seven years of study, the annual number of poultry samples sent to the laboratory ranged from a minimum of 95 in 2003 to a maximum of 217 in 2007 . The states sampled are those who hold the vast majority of broiler farms. The distribution of samples by federation states reflects the uneven spreading of farm production in the territory. There is a large concentration of poultry production in the states from the South and Southeast regions, so the annual drawing of PNCRC (Brazil, 1999) distributes the sampling taking into account the slaughter blueprint (Table 2). 
Table 1. Poultry sample distribution by year of collection

\begin{tabular}{c|cc}
\hline \multirow{2}{*}{$\begin{array}{c}\text { Year of } \\
\text { collection }\end{array}$} & \multicolumn{2}{|c}{ Frequency } \\
\cline { 2 - 3 } & $\mathbf{n}$ & $\mathbf{\%}$ \\
\hline 2002 & 118 & 11.4 \\
2003 & 95 & 9.2 \\
2004 & 109 & 10.6 \\
2005 & 128 & 12.4 \\
2006 & 190 & 18.4 \\
2007 & 217 & 21.1 \\
2008 & 174 & 16.9 \\
TOTAL & 1031 & 100.0 \\
\hline
\end{tabular}

Table 2. Sample distribution by region / state of collection

\begin{tabular}{l|cc}
\hline \multirow{2}{*}{ Region / State } & \multicolumn{2}{|c}{ Frequency } \\
\cline { 2 - 3 } & $\mathrm{n}$ & $\%$ \\
\hline North & $\mathbf{5}$ & $\mathbf{0 . 5}$ \\
Pará & 1 & 0.1 \\
Rondônia & 3 & 0.3 \\
Roraima & 1 & 0.1 \\
Northeast & & \\
Bahia & $\mathbf{1 9}$ & $\mathbf{1 . 8}$ \\
Pernambuco & 8 & 0.8 \\
Rio Grande do & 10 & 0.9 \\
North & 1 & 0.1 \\
& & \\
Midwest & & \\
Goiás & $\mathbf{1 7 8}$ & $\mathbf{1 7 . 3}$ \\
Mato Grosso & 48 & 4.6 \\
Mato Grosso do Sul & 39 & 3.8 \\
Distrito Federal & 78 & 7.6 \\
& 13 & 1.3 \\
Southeast & & \\
Espírito Santo & $\mathbf{3 0 6}$ & $\mathbf{2 9 . 7}$ \\
Minas Gerais & 1 & 0.1 \\
São Paulo & 96 & 9.3 \\
& 209 & 20.3 \\
South & & \\
Paraná & $\mathbf{5 2 3}$ & $\mathbf{5 0 . 7}$ \\
Santa Catarina & 160 & 18.2 \\
Rio Grande do Sul & 175 & 15.5 \\
\hline & & 17.0 \\
\hline
\end{tabular}

Regarding arsenic, residues were detected in $53.6 \%$ of liver samples, although no results exceeded the MRL. In kidneys, $39.7 \%$ of the samples showed measurable residues and there was no violation of the limits. Regarding lead, there was contamination in 5 liver samples and 24 kidney samples (1.5 and $3.6 \%$ respectively). In muscle tissue there was only one sample with residues. For cadmium, 3.8\% of the samples were found below MRL. Cadmium residues were found in 110 kidney samples (16.3\% of tested), but only one exceeded the legislation limits. The results showed that arsenic is the metal with the highest percentage of residue cases in poultry viscera, followed by cadmium (Table 3 ). Despite the fact that the usage of arsenic as an additive in the diet of poultry has been prohibited in Brazil, it is possible that some (especially the arsenilic acid) is still being used in farms, leading to the occurrence of residues.

The overall mean, percentiles, standard deviations and maximum and minimum values of the metals found in liver, kidneys and muscle are described in Table 4. The values below the detection limit were not used to calculate the mean values.

The overall arsenic mean in liver was $333.6 \mu \mathrm{g} / \mathrm{kg}$ and in kidneys was $137.7 \mu \mathrm{g} / \mathrm{kg}$. The arsenic in liver was $860 \mu \mathrm{g} / \mathrm{kg}(90 \%)$ and the maximum value obtained was $1410 \mu \mathrm{g} / \mathrm{kg}$, indicating the presence of samples with significant levels of residues. However, in the poultry muscle, the mean value was only $32.6 \mu \mathrm{g} / \mathrm{kg}$ and the maximum value was $256 \mu \mathrm{g} / \mathrm{kg}$, which allows us to infer that the high levels of arsenic in the liver do not compromise the muscle tissue.

The mean values of lead were $191.8 \mu \mathrm{g} / \mathrm{kg}$ and $220.8 \mu \mathrm{g} / \mathrm{kg}$ for liver and kidney, respectively. No sample reached the MRL of $500 \mu \mathrm{g} / \mathrm{kg}$ for liver or kidneys. The highest value found was $440 \mu \mathrm{g} / \mathrm{kg}$ in a kidney sample.

The cadmium mean values found in liver and kidneys were 176.6 and $286.3 \mu \mathrm{g} / \mathrm{kg}$, respectively. The maximum values found were 375 and $1300 \mu \mathrm{g} / \mathrm{kg}$ for liver and kidneys, respectively. The value of $1300 \mu \mathrm{g} / \mathrm{kg}$ found in a kidney sample was above MRL $(1000 \mu \mathrm{g} / \mathrm{kg})$. These results are similar to those found by Korsrud et al. (1985) and Craig et al. (1991). 
Assessment of heavy...

Table 3. Distribution of the results of cadmium, arsenic and lead determination in liver, kidneys and muscle of poultry

\begin{tabular}{|c|c|c|c|c|}
\hline Tissue / Metal & Tested samples* & $\begin{array}{l}\mathrm{N}^{\mathrm{o}} \text { of samples no } \\
\text { detected } * *\end{array}$ & $\begin{array}{l}\mathrm{N}^{\mathrm{o}} \text { of samples } \\
\text { below the MRL }\end{array}$ & $\begin{array}{c}\mathrm{N}^{\mathrm{o}} \text { of samples } \\
\text { above the MRL** }\end{array}$ \\
\hline \multicolumn{5}{|l|}{ Muscle } \\
\hline Arsenic & $530(51.4)$ & $459(86.6)$ & $71(13.4)$ & $0(0.0)$ \\
\hline Lead & $2(0.2)$ & $1(50.0)$ & $1(50.0)$ & $0(0.0)$ \\
\hline Cadmium & $4(0.4)$ & $4(100.0)$ & $0(0.0)$ & $0(0.0)$ \\
\hline \multicolumn{5}{|l|}{ Liver } \\
\hline Arsenic & $192(18.6)$ & $89(46.4)$ & $103(53.6)$ & $0(0.0)$ \\
\hline Lead & $341(33.1)$ & $336(98.5)$ & $5(1.5)$ & $0(0.0)$ \\
\hline Cadmium & $342(33.2)$ & $329(96.2)$ & $13(3.8)$ & $0(0.0)$ \\
\hline \multicolumn{5}{|l|}{ Kidney } \\
\hline Arsenic & $297(28.8)$ & $179(60.3)$ & $118(39.7)$ & $0(0.0)$ \\
\hline Lead & $675(65.5)$ & $651(96.4)$ & $24(3.6)$ & $0(0.0)$ \\
\hline Cadmium & $676(65.6)$ & $565(83.6)$ & $110(16.3)$ & $1(0.1)$ \\
\hline
\end{tabular}

*The percentage of tested samples related to the total sample (1031); ** The percentage of test results (not detected, detected and detected above MRL) related to the total tested samples.

Table 4. Descriptive measurements of contaminated samples (ug.kg-1)

\begin{tabular}{l|c|c|c|c|c|c|c}
\hline \multirow{2}{*}{ Tissue / Metal } & \multicolumn{7}{|c}{ Descriptive measurements } \\
\cline { 2 - 8 } $\begin{array}{l}\text { Muscle } \\
\text { Arsenic }\end{array}$ & Minimum & Maximum & P10 & P50 & P90 & Mean value & SD \\
$\begin{array}{l}\text { Liver } \\
\text { Arsenic }\end{array}$ & 10.0 & 256.0 & 10.0 & 25.0 & 54.0 & 32.6 & 35.3 \\
$\begin{array}{l}\text { Lead } \\
\text { Cadmium }\end{array}$ & 10.0 & 1410.0 & 10.0 & 230.0 & 860.0 & 333.6 & 360.1 \\
Kidney & 165.0 & 238.0 & 165.0 & 171.0 & - & 191.8 & 34.6 \\
Arsenic & 90.0 & 375.0 & 90.0 & 170.0 & 333.0 & 176.6 & 84.1 \\
Lead & 10.0 & 760.0 & 10.0 & 85.0 & 325.0 & 137.7 & 152.9 \\
Cadmium & 30.0 & 440.0 & 150.0 & 160.0 & 353.5 & 220.8 & 85.7 \\
\hline
\end{tabular}

Table 5 describes the number of samples tested and quantified (with their percentage) of each of the tissues by state and region of the country. Arsenic had a greater percentage of contaminated liver samples in the Southeast region $(64.8 \%)$, followed by the Northeast $(54.3 \%)$, Midwest $(54.3 \%)$ and South region (43\%). The percentage of positive samples for arsenic in liver was high in all regions. In kidneys, the highest quantification percentage happened in the Northeast (100\%) and Southeast (45.3\%), followed by the Midwest and South regions (38.2\% and $36.5 \%$ respectively), giving emphasis to São Paulo state, which showed $61 \%$ of samples contaminated. In the North, as in the Northeast, although the rates of contamination were high (50 and $100 \%$, respectively) the sampling in the states of this region was small, preventing inferences regarding metal contamination in samples from these regions.

Lead was quantified in only $1.9 \%$ of the liver samples from the Midwest, $1.7 \%$ of the samples from the South, and $0.9 \%$ of the samples from the Southeast region. The Northeast and North region did not have any quantified samples. In kidney samples the contamination rate was $4.1 \%$ in the South region, $4 \%$ for the Midwest and $2.1 \%$ in the Southeast region. The Northeast did not have any measured kidney samples and in the North there was only one out four samples analyzed with residues of lead (25\%). 
Table 5. Distribution of analyzed samples in different states/regions

\begin{tabular}{|c|c|c|c|c|c|c|c|c|c|}
\hline \multirow{2}{*}{ Region / State } & \multicolumn{3}{|c|}{ Muscle } & \multicolumn{3}{|c|}{ Liver } & \multicolumn{3}{|c|}{ Kidney } \\
\hline & Arsenic & Lead & Cadmium & Arsenic & Lead & Cadmium & Arsenic & Lead & Cadmium \\
\hline North & $\begin{array}{l}0^{*} / 3^{* *} \\
(0.0)^{* * *}\end{array}$ & - & (5) & 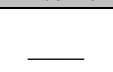 & $\begin{array}{c}0 / 1 \\
(0.0)\end{array}$ & $\begin{array}{c}0 / 1 \\
(0.0)\end{array}$ & $\begin{array}{c}1 / 2 \\
(50.0)\end{array}$ & $\begin{array}{c}1 / 4 \\
(25.0)\end{array}$ & $\begin{array}{c}0 / 4 \\
(0.0)\end{array}$ \\
\hline Pará & & & & & & & $1 / 1$ & $0 / 1$ & $0 / 1$ \\
\hline Rondônia & $0 / 3(\Omega \Omega)$ & & & & $0 / 1$ & $0 / 1$ & & $0 / 2$ & $0 / 2$ \\
\hline Roraima & $0 / 3(0.0)$ & & & & & & $\begin{array}{c}\overline{0 / 1} \\
(0.0)\end{array}$ & $\begin{array}{c}(0.0) \\
1 / 1 \\
(100.0)\end{array}$ & $\begin{array}{c}(0.0) \\
0 / 1 \\
(0.0)\end{array}$ \\
\hline Northeast & $\begin{array}{c}1 / 9 \\
(11.1)\end{array}$ & - & - & $\begin{array}{c}4 / 7 \\
(57.1)\end{array}$ & $\begin{array}{c}0 / 8 \\
(0.0)\end{array}$ & $\begin{array}{c}0 / 8 \\
(0.0)\end{array}$ & $\begin{array}{c}2 / 2 \\
(100.0)\end{array}$ & $\begin{array}{l}0 / 10 \\
(0.0)\end{array}$ & $\begin{array}{l}0 / 10 \\
(0.0)\end{array}$ \\
\hline Bahia & $\begin{array}{c}0 / 4 \\
(0.0)\end{array}$ & 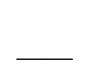 & 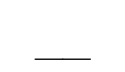 & $\begin{array}{c}2 / 2 \\
(100.0)\end{array}$ & $\begin{array}{c}0 / 3 \\
(0.0)\end{array}$ & $\begin{array}{c}0 / 3 \\
(0.0)\end{array}$ & $\begin{array}{c}1 / 1 \\
(100.0)\end{array}$ & $\begin{array}{c}0 / 4 \\
(0.0)\end{array}$ & $\begin{array}{c}0 / 4 \\
(0.0)\end{array}$ \\
\hline Pernambuco & $\begin{array}{l}1 / 5 \\
(20.0)\end{array}$ & & & $\begin{array}{c}2 / 4 \\
(50.0)\end{array}$ & $\begin{array}{c}0 / 4 \\
(0.0)\end{array}$ & $\begin{array}{c}0 / 4 \\
(0.0)\end{array}$ & $\begin{array}{c}1 / 1 \\
(100.0)\end{array}$ & $\begin{array}{c}0 / 6 \\
(0.0)\end{array}$ & $\begin{array}{c}0 / 6 \\
(0.0)\end{array}$ \\
\hline Rio Grande do North & - & & & $0 / 1(0.0)$ & $0 / 1(0.0)$ & $0 / 1(0.0)$ & $(100.0)$ & & \\
\hline Midwest & $\begin{array}{c}7 / 70 \\
(10.0)\end{array}$ & - & $\begin{array}{c}0 / 1 \\
(0.0)\end{array}$ & $\begin{array}{l}19 / 35 \\
(54.3)\end{array}$ & $\begin{array}{l}1 / 53 \\
(1.9)\end{array}$ & $\begin{array}{l}2 / 54 \\
(3.7)\end{array}$ & $\begin{array}{l}26 / 72 \\
(38.2)\end{array}$ & $\begin{array}{c}5 / 124 \\
(4)\end{array}$ & $\begin{array}{r}33 / 124 \\
(26.6)\end{array}$ \\
\hline Goiás & $\begin{array}{c}3 / 25 \\
(12.0)\end{array}$ & 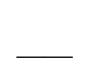 & - & $\begin{array}{c}3 / 8 \\
(37.5)\end{array}$ & $\begin{array}{l}0 / 13 \\
(0.0)\end{array}$ & $\begin{array}{l}0 / 13 \\
(0.0)\end{array}$ & $\begin{array}{c}8 / 14 \\
(57.1)\end{array}$ & $\begin{array}{l}1 / 34 \\
(2.9)\end{array}$ & $\begin{array}{c}4 / 34 \\
(11.8)\end{array}$ \\
\hline Mato Grosso & $\begin{array}{l}0 / 12 \\
(0.0)\end{array}$ & & $\begin{array}{c}0 / 1 \\
(0.0)\end{array}$ & $\begin{array}{c}2 / 4 \\
(50.0)\end{array}$ & $\begin{array}{c}0 / 4 \\
(0.0)\end{array}$ & $\begin{array}{c}1 / 5 \\
(20.0)\end{array}$ & $\begin{array}{l}1 / 23 \\
(4.3)\end{array}$ & $\begin{array}{l}3 / 35 \\
(8.6)\end{array}$ & $\begin{array}{l}19 / 35 \\
(54.3)\end{array}$ \\
\hline Mato Grosso do Sul & $\begin{array}{c}3 / 26 \\
(11.5)\end{array}$ & {[} & & $\begin{array}{l}13 / 22 \\
(59.1)\end{array}$ & $\begin{array}{l}0 / 33 \\
(0.0)\end{array}$ & $\begin{array}{l}1 / 33 \\
(3.0)\end{array}$ & $\begin{array}{l}16 / 30 \\
(53.3)\end{array}$ & $\begin{array}{l}0 / 45 \\
(0.0)\end{array}$ & $\begin{array}{c}8 / 45 \\
(17.8)\end{array}$ \\
\hline Distrito Federal & $\begin{array}{c}1 / 7 \\
(14.3)\end{array}$ & & - & $\begin{array}{c}1 / 1 \\
(100.0)\end{array}$ & $\begin{array}{c}1 / 3 \\
(33.3)\end{array}$ & $\begin{array}{c}0 / 3 \\
(0.0)\end{array}$ & $\begin{array}{c}1 / 5 \\
(20.0)\end{array}$ & $\begin{array}{c}1 / 10 \\
(10.0)\end{array}$ & $\begin{array}{c}2 / 10 \\
(20.0)\end{array}$ \\
\hline Southeast & $\begin{array}{c}25 / 134 \\
(18.7)\end{array}$ & $\begin{array}{c}0 / 1 \\
(0.0)\end{array}$ & $\begin{array}{c}0 / 2 \\
(0.0)\end{array}$ & $\begin{array}{l}46 / 71 \\
(64.8)\end{array}$ & $\begin{array}{r}1 / 107 \\
(0.9)\end{array}$ & $\begin{array}{c}0 / 107 \\
(0.0)\end{array}$ & $\begin{array}{l}43 / 95 \\
(45.3)\end{array}$ & $\begin{array}{c}4 / 192 \\
(2.1)\end{array}$ & $\begin{array}{c}24 / 193 \\
(12.4)\end{array}$ \\
\hline Espírito Santo & $\begin{array}{c}0 / 1 \\
(0.0)\end{array}$ & & & & & {$[-$} & & $0 / 1(0.0)$ & $\begin{array}{c}0 / 1 \\
(0.0)\end{array}$ \\
\hline Minas Gerais & $\begin{array}{l}3 / 38 \\
(7.9)\end{array}$ & $\begin{array}{c}0 / 1 \\
(0.0)\end{array}$ & $\begin{array}{c}0 / 1 \\
(0.0)\end{array}$ & $\begin{array}{l}13 / 22 \\
(59.1)\end{array}$ & $\begin{array}{l}0 / 30 \\
(0.0)\end{array}$ & $\begin{array}{l}0 / 30 \\
(0.0)\end{array}$ & $\begin{array}{c}7 / 36 \\
(19.4)\end{array}$ & $\begin{array}{l}3 / 65 \\
(4.6)\end{array}$ & $\begin{array}{l}13 / 66 \\
(19.7)\end{array}$ \\
\hline São Paulo & $\begin{array}{l}22 / 95 \\
(23.2)\end{array}$ & . & $\begin{array}{c}0 / 1 \\
(0.0)\end{array}$ & $\begin{array}{l}33 / 49 \\
(67.3)\end{array}$ & $\begin{array}{l}1 / 77 \\
(1.3)\end{array}$ & $\begin{array}{l}0 / 77 \\
(0.0)\end{array}$ & $\begin{array}{c}36 / 59 \\
(61)\end{array}$ & $\begin{array}{l}1 / 126 \\
(0.8)\end{array}$ & $\begin{array}{c}11 / 126 \\
(8.7)\end{array}$ \\
\hline South & $\begin{array}{c}39 / 314 \\
(12.4)\end{array}$ & $\begin{array}{c}1 / 1 \\
(100.0)\end{array}$ & $\begin{array}{c}0 / 1 \\
(0.0)\end{array}$ & $\begin{array}{l}34 / 79 \\
(43.0)\end{array}$ & $\begin{array}{c}3 / 172 \\
(1.7)\end{array}$ & $\begin{array}{c}11 / 172 \\
(6.4)\end{array}$ & $\begin{array}{c}46 / 126 \\
(36.5)\end{array}$ & $\begin{array}{c}14 / 345 \\
(4.1)\end{array}$ & $\begin{array}{c}54 / 345 \\
(15.7)\end{array}$ \\
\hline Paraná & $\begin{array}{c}10 / 111 \\
(9.0)\end{array}$ & $\begin{array}{c}1 / 1 \\
(100.0)\end{array}$ & - & $\begin{array}{l}11 / 28 \\
(39.3)\end{array}$ & $\begin{array}{l}1 / 59 \\
(1.7)\end{array}$ & $\begin{array}{l}0 / 59 \\
(0.0)\end{array}$ & $\begin{array}{l}17 / 51 \\
(33.3)\end{array}$ & $\begin{array}{c}6 / 128 \\
(4.7)\end{array}$ & $\begin{array}{c}13 / 128 \\
(10.2)\end{array}$ \\
\hline Santa Catarina & $\begin{array}{l}8 / 96 \\
(8.3)\end{array}$ & - & $\begin{array}{c}0 / 1 \\
(0.0)\end{array}$ & $\begin{array}{c}7 / 22 \\
(31.8)\end{array}$ & $\begin{array}{l}2 / 57 \\
(3.5)\end{array}$ & $\begin{array}{l}2 / 57 \\
(3.5)\end{array}$ & $\begin{array}{l}11 / 39 \\
(28.2)\end{array}$ & $\begin{array}{c}3 / 102 \\
(2.9)\end{array}$ & $\begin{array}{l}16 / 102 \\
(15.7)\end{array}$ \\
\hline Rio Grande do Sul & $\begin{array}{c}21 / 107 \\
(19.6)\end{array}$ & - & $\overline{-}$ & $\begin{array}{l}16 / 29 \\
(55.2)\end{array}$ & $0 / 56(0.0)$ & $\begin{array}{c}9 / 56 \\
(16.1)\end{array}$ & $\begin{array}{l}18 / 36 \\
(50.0)\end{array}$ & $\begin{array}{r}5 / 115 \\
(4.3)\end{array}$ & $\begin{array}{c}25 / 115 \\
(21.7)\end{array}$ \\
\hline
\end{tabular}

* number of contaminated samples; ${ }^{* *}$ Total number of analyzed samples; ${ }^{* * *}$ Percentage of contaminated samples.

Table 6. Swine sample distribution by year of collection

\begin{tabular}{c|c|c}
\hline Year of & \multicolumn{2}{|c}{ Frequency } \\
\cline { 2 - 3 } collection & $\mathrm{n}$ & $\%$ \\
\hline 2002 & 25 & 2.6 \\
2003 & 15 & 1.6 \\
2004 & 71 & 7.5 \\
2005 & 99 & 10.5 \\
2006 & 255 & 26.9 \\
2007 & 251 & 26.5 \\
2008 & 231 & 24.4 \\
Total & 947 & 100.0 \\
\hline
\end{tabular}

During the seven years of the experiment, the annual number of swine samples sent to the laboratory ranged from a minimum of 15 in 2003 to a maximum of 255 in 2007.

The states sampled are those that have a swine farming tradition. The distribution of samples by federation states reflects the uneven spreading of farm production in the territory. There is a large concentration of swine production in the states in the South of Brazil, which justifies the sampling concentration in this region (Table 7). 
Table 7. Sample distribution by region / state of collection

\begin{tabular}{l|c|c}
\hline \multirow{2}{*}{ Region / State } & \multicolumn{2}{|c}{ Frequency } \\
\cline { 2 - 3 } & $\mathrm{n}$ & $\%$ \\
\hline North & $\mathbf{2}$ & $\mathbf{0 . 2}$ \\
Amazonas & 1 & 0.1 \\
Roraima & 1 & 0.1 \\
& & \\
Midwest & $\mathbf{1 7 9}$ & $\mathbf{1 8 . 9}$ \\
Goiás & 49 & 5.2 \\
Mato Grosso & 29 & 3.1 \\
Mato Grosso do Sul & 100 & 10.5 \\
Distrito Federal & 1 & 0.1 \\
& & \\
Southeast & $\mathbf{1 3 1}$ & $\mathbf{1 3 . 9}$ \\
Minas Gerais & 85 & 9.0 \\
São Paulo & 46 & 4.9 \\
South & & \\
Paraná & $\mathbf{6 3 5}$ & $\mathbf{6 7 . 0}$ \\
Santa Catarina & 138 & 14.6 \\
Rio Grande do Sul & 257 & 27.1 \\
\hline
\end{tabular}

In swine, arsenic residues were detected in $15.3 \%$ of liver samples, although no results have exceeded the MRL. In kidneys, $14.2 \%$ of samples showed measurable residues. However, there was no violation of limits. Regarding lead levels, 7 liver samples and 18 kidney samples were contaminated (2.6 and $2.7 \%$ respectively). Cadmium was found below MRL in $14.9 \%$ of the analyzed samples. In kidneys, 448 samples (67.8\% of the total tested) had cadmium residues and 3 samples exceeded the legislation limits. The results showed that cadmium is the metal with the highest percentage of residue cases in swine viscera, distantly followed by arsenic. Nevertheless, during the seven years of this study only three kidney samples had cadmium concentrations above $1000 \mu \mathrm{g} / \mathrm{kg}$ (Table 8).

The mean values, percentiles, standard deviations and maximum and minimum values of the metals found in liver, kidneys and muscle of swine are described in Table 9. The mean values of arsenic found in liver and kidneys were 58.5 and $57.2 \mu \mathrm{g} / \mathrm{kg}$, respectively. The maximum value obtained was $720 \mu \mathrm{g} / \mathrm{kg}$, which confirms the absence of significant residues. For cadmium the mean values found in liver and kidneys were 172.1 and $217.9 \mu \mathrm{g} / \mathrm{kg}$, respectively. The maximum values found were 900 and 2534 $\mu \mathrm{g} / \mathrm{kg}$ for liver and kidneys, respectively. Despite being found in only four samples, these values were considered extremely high, which certainly evokes a specific problem with the swine farm production. The mean levels of lead were 281.4 and $207 \mu \mathrm{g} / \mathrm{kg}$, for liver and kidney, respectively. No sample reached the MRL for liver and kidneys. The highest value was $420 \mu \mathrm{g} / \mathrm{kg}$ in the kidney sample.

Table 8. Distribution of the cadmium, arsenic and lead determination results in liver, kidneys and muscle of swine

\begin{tabular}{|c|c|c|c|c|}
\hline Tissue/Metal & Tested samples* & $\begin{array}{l}\text { Samples not } \\
\text { Detected } * *\end{array}$ & $\begin{array}{l}\text { Samples detected } \\
\text { below the MRL** }\end{array}$ & $\begin{array}{l}\text { Samples detected } \\
\text { above MRL** }\end{array}$ \\
\hline \multicolumn{5}{|l|}{ Muscle } \\
\hline Arsenic & $3(0.3)$ & $3(100.0)$ & $0(0.0)$ & $0(0.0)$ \\
\hline Lead & $0(0.0)$ & - & - & - \\
\hline Cadmium & $4(0.4)$ & $4(100.0)$ & $0(0.0)$ & $0(0.0)$ \\
\hline \multicolumn{5}{|l|}{ Liver } \\
\hline Arsenic & $360(38.0)$ & 305 (84.7) & $55(15.3)$ & $0(0.0)$ \\
\hline Lead & $272(28.7)$ & $265(97.4)$ & $7(2.6)$ & $0(0.0)$ \\
\hline Cadmium & $275(29.0)$ & $233(84.6)$ & $41(14.9)$ & $1(0.5)$ \\
\hline \multicolumn{5}{|l|}{ Kidney } \\
\hline Arsenic & $571(60.3)$ & $490(85.8)$ & $81(14.2)$ & $0(0.0)$ \\
\hline Lead & $661(69.8)$ & $643(97.3)$ & $18(2.7)$ & $0(0.0)$ \\
\hline Cadmium & $661(69.8)$ & $210(31.8)$ & $448(67.8)$ & $3(0.4)$ \\
\hline
\end{tabular}

Note: *The percentage of tested samples related to the total sample (947)

** The percentage of test results (not detected, detected and detected above MRL) related to the total tested samples. 
Table 9. Descriptive measurements of contaminated samples (ug. $\mathrm{kg}^{-1}$ )

\begin{tabular}{l|c|c|c|c|c|c|c}
\hline \multirow{2}{*}{ Tissue / Metal } & \multicolumn{7}{c}{ Descriptive measurements } \\
\cline { 2 - 9 } & Minimum & Maximum & P10 & P50 & P90 & Mean value & SD \\
\hline Liver & & & & & & & \\
Arsenic & 10.0 & 720.0 & 10.0 & 30.0 & 135.6 & 58.5 & 101.4 \\
Lead & 170.0 & 384.0 & 170.0 & 311.0 & - & 281.4 & 88.4 \\
Cadmium & 90.0 & 900.0 & 91.0 & 130.0 & 297.2 & 172.1 & 137.4 \\
Kidney & & & & & & & \\
Arsenic & 10.0 & 390.0 & 10.0 & 20.0 & 166.0 & 57.2 & 69.4 \\
Lead & 134.0 & 420.0 & 149.3 & 169.5 & 368.7 & 207.2 & 77.5 \\
Cadmium & 90.0 & 2534.0 & 100.0 & 146.0 & 418.0 & 217.9 & 202.2 \\
\hline
\end{tabular}

Table 10 describes the number of samples tested and quantified (with their percentage) of each of the tissues divided by state and region of the country. Arsenic had a greater percentage of contaminated liver samples in the Midwest (16.9\%), followed by the South (16.5\%), and Southeast region $(7.8 \%)$. The Northeast region did not show any liver samples contaminated with arsenic. In kidneys, the highest percentage of quantification happened in the North $(100 \%)$ and the South $(15.3 \%)$, followed by the Midwest and the Southeast regions $(12.6 \%$ and $10.3 \%$ respectively). In the North, only one sample was analyzed. Lead was quantified in only $2.4 \%$ of the liver samples from the Midwest region, $2.1 \%$ of the samples from the South, and 5\% of the samples from the Southeast region. The North region did not have quantified samples. The contamination rate in kidney samples was $3.5 \%$ in the South, $0.7 \%$ for the Midwest and $2.2 \%$ for the Southeast region. The North did not have any measured kidney samples. Regarding cadmium, the contamination rates in the liver samples were $22 \%$ for the Southeast, $12.2 \%$ for the Midwest and $14.6 \%$ for the South region. In the North region no sample was above the detection limit. In kidneys the number of positive samples was $75.9 \%$ in the Midwest, $65.9 \%$ in the South and $67.4 \%$ in the Southeast region. In the North region only one sample was analyzed and presented quantifiable residues. The presence of cadmium residues was significant in all regions of the country, allowing us to infer that there are common factors that lead to the contamination in all regions. Again, as observed in cattle samples, the diet should be the main factor leading to metal residues.
During the seven years of study (2002-2008), only 5 out of 1978 tested samples violated the Brazilian law. This low percentage $(0.25 \%)$ confirms the efficiency of the National Control Program (PNCRC). However, even with low levels of violation, monitoring is essential, since the number of samples with residues was often greater than the number of violations, and in some cases, such as cadmium in the kidneys, the majority of samples contained quantifiable residues with often near limit levels. Thus, we cannot limit our conclusions to the analysis of the number of samples with concentrations above the legal limit, even as these limits may change due to the increase of scientific knowledge regarding the deleterious effects of these metals for human and animal health (Table 11).

The levels of arsenic have decreased over time in swine and especially in poultry. The prohibition of the usage of arsenicals as growth promoters appears to be one of the factors that explain this sharp decline in the contamination levels, besides the greater efficiency of the control exercised by PNCR. Lead levels in contaminated samples were low in all species during all years. The cadmium contamination in swine continues high (with levels between 40 and $60 \%$ of total samples analyzed), despite the decrease that happened in the year 2003. Between 2007 and 2008, cadmium contamination increased from 44 to $62 \%$. On other hand, poultry showed lower levels of this metal (up to $24 \%$ in 2005). Nevertheless, the data does not indicate a downward trend regarding cadmium contamination. 
Assessment of heavy...

Table 10. Distribution of analyzed samples in different states/regions

\begin{tabular}{|c|c|c|c|c|c|c|c|c|c|}
\hline \multirow{2}{*}{ Region / State } & \multicolumn{3}{|c|}{ Muscle } & \multicolumn{3}{|c|}{ Liver } & \multicolumn{3}{|c|}{ Kidney } \\
\hline & Arsenic & Lead & Cadmium & Arsenic & Lead & Cadmium & Arsenic & Lead & Cadmium \\
\hline North & 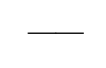 & - & 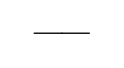 & $\begin{array}{l}0 \% / 11^{* *} \\
(0.0)^{* * *}\end{array}$ & $0 / 1(0.0)$ & $\begin{array}{c}0 / 1 \\
(0.0)\end{array}$ & $\begin{array}{c}1 / 1 \\
(100.0)\end{array}$ & $0 / 1(0.0)$ & $\begin{array}{c}1 / 1 \\
(100.0)\end{array}$ \\
\hline Amazonas & & & 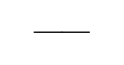 & $\begin{array}{c}0 / 1 \\
(0.0)\end{array}$ & $0 / 1(0.0)$ & $\begin{array}{c}0 / 1 \\
(0.0)\end{array}$ & - & $\longrightarrow$ & $\longrightarrow$ \\
\hline Roraima & & & 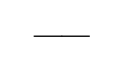 & $\longrightarrow$ & - & - & $\begin{array}{c}1 / 1 \\
(100.0)\end{array}$ & $0 / 1(0.0)$ & $\begin{array}{c}1 / 1 \\
(100.0)\end{array}$ \\
\hline Midwest & & & & $\begin{array}{l}10 / 59 \\
(16.9)\end{array}$ & $\begin{array}{l}1 / 41 \\
(2.4)\end{array}$ & $\begin{array}{c}5 / 41 \\
(12.2)\end{array}$ & $\begin{array}{l}15 / 119 \\
(12.6)\end{array}$ & $\begin{array}{l}1 / 137 \\
(0.7)\end{array}$ & $\begin{array}{c}104 / 137 \\
(75.9)\end{array}$ \\
\hline Goiás & & & & $\begin{array}{l}5 / 25 \\
(20.0)\end{array}$ & $\begin{array}{l}0 / 20 \\
(0.0)\end{array}$ & $\begin{array}{l}1 / 20 \\
(5.0)\end{array}$ & $\begin{array}{l}4 / 23 \\
(17.4)\end{array}$ & $0 / 28(0)$ & $\begin{array}{l}15 / 28 \\
(53.6)\end{array}$ \\
\hline Mato Grosso & & & & $\begin{array}{l}2 / 14 \\
(14.3)\end{array}$ & $\begin{array}{c}1 / 7 \\
(14.3)\end{array}$ & $\begin{array}{c}2 / 7 \\
(28.6)\end{array}$ & $\begin{array}{l}1 / 15 \\
(6.7)\end{array}$ & $\begin{array}{l}1 / 22 \\
(4.5)\end{array}$ & $\begin{array}{l}20 / 22 \\
(90.9)\end{array}$ \\
\hline $\begin{array}{c}\text { Mato Grosso do } \\
\text { Sul }\end{array}$ & & & & $\begin{array}{l}3 / 20 \\
(15.0)\end{array}$ & $\begin{array}{l}0 / 14 \\
(0.0)\end{array}$ & $\begin{array}{c}2 / 14 \\
(14.3)\end{array}$ & $\begin{array}{l}10 / 80 \\
(12.5)\end{array}$ & $0 / 86(0)$ & $\begin{array}{l}68 / 86 \\
(79.1)\end{array}$ \\
\hline Distrito Federal & & & & - & 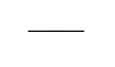 & 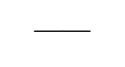 & $\begin{array}{c}0 / 1 \\
(0.0)\end{array}$ & $0 / 1(0)$ & $\begin{array}{c}1 / 1 \\
(100.0)\end{array}$ \\
\hline Southeast & & & $\begin{array}{c}0 / 2 \\
(0.0)\end{array}$ & $\begin{array}{l}4 / 51 \\
(7.8)\end{array}$ & $\begin{array}{l}2 / 40 \\
(5)\end{array}$ & $\begin{array}{l}9 / 41 \\
(22)\end{array}$ & $\begin{array}{c}8 / 78 \\
(10.3)\end{array}$ & $\begin{array}{l}2 / 89 \\
(2.2)\end{array}$ & $\begin{array}{l}60 / 89 \\
(67.4)\end{array}$ \\
\hline Minas Gerais & & & $\begin{array}{c}0 / 2 \\
(0.0)\end{array}$ & $\begin{array}{l}3 / 39 \\
(7.7)\end{array}$ & $\begin{array}{l}1 / 31 \\
(3.2)\end{array}$ & $\begin{array}{c}6 / 32 \\
(18.8)\end{array}$ & $\begin{array}{c}5 / 44 \\
(11.4)\end{array}$ & $\begin{array}{l}2 / 52 \\
(3.8)\end{array}$ & $\begin{array}{l}34 / 52 \\
(65.4)\end{array}$ \\
\hline São Paulo & & & 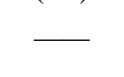 & $\begin{array}{l}1 / 12 \\
(8.3)\end{array}$ & $\begin{array}{c}1 / 9 \\
(11.1)\end{array}$ & $\begin{array}{c}3 / 9 \\
(33.3)\end{array}$ & $\begin{array}{l}3 / 34 \\
(8.8)\end{array}$ & $0 / 37(0)$ & $\begin{array}{l}26 / 37 \\
(70.3)\end{array}$ \\
\hline South & $0 / 3(0.0)$ & & $\begin{array}{c}0 / 2 \\
(0.0)\end{array}$ & $\begin{array}{c}41 / 249 \\
(16.5)\end{array}$ & $\begin{array}{l}4 / 190 \\
(2.1)\end{array}$ & $\begin{array}{c}28 / 192 \\
(14.6)\end{array}$ & $\begin{array}{c}57 / 373 \\
(15.3)\end{array}$ & $\begin{array}{c}15 / 434 \\
(3.5)\end{array}$ & $\begin{array}{c}286 / 434 \\
(65.9)\end{array}$ \\
\hline Paraná & & & 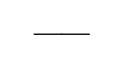 & $\begin{array}{l}8 / 60 \\
(13.3)\end{array}$ & $\begin{array}{l}3 / 47 \\
(6.4)\end{array}$ & $\begin{array}{c}5 / 47 \\
(10.6)\end{array}$ & $\begin{array}{l}3 / 75 \\
(4.0)\end{array}$ & $\begin{array}{l}1 / 88 \\
(1.1)\end{array}$ & $\begin{array}{l}46 / 88 \\
(52.3)\end{array}$ \\
\hline Santa Catarina & $\begin{array}{c}0 / 1 \\
(0.0)\end{array}$ & & $\begin{array}{c}0 / 1 \\
(0.0)\end{array}$ & $\begin{array}{l}4 / 89 \\
(4.5)\end{array}$ & $\begin{array}{l}0 / 70 \\
(0.0)\end{array}$ & $\begin{array}{l}14 / 71 \\
(19.7)\end{array}$ & $\begin{array}{c}21 / 164 \\
(12.8)\end{array}$ & $\begin{array}{l}4 / 183 \\
(2.2)\end{array}$ & $\begin{array}{c}128 / 183 \\
(69.9)\end{array}$ \\
\hline $\begin{array}{c}\text { Rio Grande do } \\
\text { Sul }\end{array}$ & $\begin{array}{c}0 / 2 \\
(0.0)\end{array}$ & & $\begin{array}{c}0 / 1 \\
(0.0)\end{array}$ & $\begin{array}{c}29 / 100 \\
(29.0)\end{array}$ & $\begin{array}{l}1 / 73 \\
(1.4)\end{array}$ & $\begin{array}{c}9 / 74 \\
(12.2)\end{array}$ & $\begin{array}{c}33 / 134 \\
(24.6)\end{array}$ & $\begin{array}{c}10 / 163 \\
(6.1)\end{array}$ & $\begin{array}{c}112 / 163 \\
(68.7)\end{array}$ \\
\hline
\end{tabular}

Table 11. Provenance of the samples above the MRL

\begin{tabular}{cccccc}
\hline Species & Tissue & Metal & State & City & $\mathrm{N}^{\circ}$ of samples \\
\hline Poultry & Kidney & Cadmium & MT & Tangará da Serra & 1 \\
& & & & & \\
& Liver & Cadmium & SC & Videira & 1 \\
Swine & & & MG & Coimbra & 1 \\
& Kidney & Cadmium & RS & Pareci Novo & 1 \\
Total & & & SC & Guaraciaba & 1 \\
\hline
\end{tabular}

\section{CONCLUSIONS}

Regarding arsenic residues, its occurrence has decreased significantly over time possibly due to greater control exercised by the government, especially in the potential sources of arsenic in the diet, such as organic arsenic. The lead residues in liver, kidneys and muscle were not significant in any of the animal species studied. Cadmium contamination has a tendency to increase, which allows us to infer that more effective control measures must be taken to ensure the safety of animal products regarding this toxic metal, even though few samples have actually reached the MRL. 


\section{REFERENCES}

BRASIL. Ministério da Agricultura. Instrução Normativa $\mathrm{n}^{\circ} 42$, de 20 de dezembro de 1999. Programa Nacional de Controle de Resíduos em Produtos de Origem Animal. Diário Oficial da União. Brasília, DF: Ministério da Agricultura, Secretaria de Inspeção de Produto Animal, 213 227, 1999.

CAREY, A.M.; SCHECKEL, K.G.; LOMBI, E. et al. Grain unloading of arsenic species in rice. Plant Physiol., v.152, p.309-319, 2010.

CRAIG, D.C.S.; CHAN, W.; SASCHENBRECKER, P.W. Multielement concentrations in liver and kidney tissues from five species of Canadian slaughter animals. J. Assoc. Anal. Chem., v.74, p.587-591, 1991.

EFSA (European Food Safety Authority). Opinion of the Scientific Panel on Contaminants in the Food Chain on a request from the Commission related to lead as undesirable substance in animal feed. EFSA J, v.71, p.1-20, 2004.

EFSA (European Food Safety Authority). Scientific opinion on arsenic in food. EFSA panel on contaminants in the food chain (CONTAM). EFSA J, v.1351, p.1-199, 2009a.

EFSA (European Food Safety Authority). Cadmium in food. Scientific opinion of the panel on contaminants in the food chain. EFSA J, v.980, p.1-139, 2009b.

GUNAWARDENA, J.; EGODAWATTA, P.; AYOKO, G.A. et al. Atmospheric deposition as a souce of heavy metals in urban stormwater. Atmospheric Environ., v.68, p.235-242, 2013.

KORSRUD, G.; MELDRUM, J.; SALISBURY, C. Trace element levels in liver and kidney from cattle, swine and poultry slaughtered in Canada. Can. J. Comp. Med., v.49, p.159-163, 1985.

PAPPAS, R.S.; POLZIN, G.M.; WATSON, C.H. et al. Cadmium, lead and thalium in smoke particulate from counterfeit cigarrets compared to authentic US brand. Food Chem. Toxicol., v.45, p.202-209, 2007.

PULLES, T.; VAN DER GON, H.D.; APPELMAN, W. et al. Emission factors for heavy metals from dieses and petrol used in European vehicles. Atmospheric Environ., v.61, p.641-651, 2012.

REEVES, P.G.; CHANEY, R.L. Bioavailability as an issue in risk assessment and management of food cadmium: a review. Sci. Total Environ., v.398, p.13-19, 2008.

SMEDLEY, P.L.; KINNIBURGH, D.G. A review of the source, behavior and distribution of arsenic in natural waters. Appl. Geochem., v.17, p.517-568, 2002.

TAJKARIMI, M.; FAGHIH, M.A.; POURSOLTANI, H. et al. Lead residue levels in raw milk from different regions of Iran. Food Control, v.19, p.495-498, 2008.

USDA (United States Department of Agriculture - Food Safety and Inspection Service - Office of Public Health and Science). Determination of arsenic by atomic absorption spectrophotometry. SOP CLG-ARS.03, 3, Washington DC: USDA/FSIS, 2001. 16p.

WHO (World Health Organization). Health risks of heavy metals from long-range transboundary air pollution, 9789289071796 WHO Regional Office for Europe, Copenhagen, Denmark, 2007. 